\title{
Pengaruh Flushing Berbasis Pakan Lokal terhadap Pertumbuhan dan Birahi Kambing Kejobong Betina Dewasa
}

\author{
Socheh, $\mathrm{M}^{1}$., Ismaya ${ }^{2}$, I.G.S. Budisatria ${ }^{2}$ dan Kustantinah ${ }^{2}$ \\ ${ }^{1}$ Fakultas Peternakan Universitas Jenderal Soedirman, Purwokerto \\ ${ }^{2}$ Fakultas Peternakan Universitas Gadjah Mada, Yogyakarta \\ E-mail: m_socheh1@yahoo.com
}

\begin{abstract}
ABSTRAK
Tujuan penelitian ini adalah untuk mengetahui pengaruh flushing berbasis pakan lokal terhadap pertumbuhan, tanggap birahi, awal birahi, dan lama birahi kambing Kejobong betina dewasa. Dua puluh ekor kambing Kejobong betina dewasa dengan rataan bobot hidup awal $26,6 \pm 1,7 \mathrm{~kg}$ digunakan di dalam penelitian ini. Seluruh ternak ditempatkan secara acak kedalam dua perlakuan pakan, yaitu: perlakuan pakan non-flushing $\left(p_{0}\right)$ dan flushing $\left(p_{1}\right)$ dengan ulangan sebanyak 10 kali. Peubah yang diamati adalah $\mathrm{PBBH}$, tanggap birahi, awal birahi dan lama birahi. Data yang diperoleh dianalisis dengan Uji t. Hasil penelitian menunjukkan bahwa PBBH pada kelompok flushing lebih tinggi $(\mathrm{P} \leq 0,05)$ daripada kelompok non-flushing. Tanggap birahi kambing betina dewasa pada kelompok flushing dan nonflushing menghasilkan masing-masing sebanyak 100\%. Awal birahi kambing betina dewasa pada kelompok flushing lebih cepat daripada ternak pada kelompok non-flushing $(\mathrm{P} \leq 0,05)$. Birahi pada kelompok flushing $(\mathrm{P} \leq 0,05)$ lebih lama daripada kelompok non-flushing $(\mathrm{P} \leq 0,05)$. Dapat disimpulkan bahwa flushing pada kambing Kejobong betina dewasa dapat meningkatkan $\mathrm{PBBH}$, mempercepat timbulnya awal birahi dan memperpanjang lama birahi.
\end{abstract}

Kata kunci: flushing, non-flushing, pertumbuhan, birahi, kambing Kejobong

\section{The Effect of Flushing Based Local Feed on Growth and Estrous of Kejobong Doe}

\begin{abstract}
The purposes of this study were to: 1 . Study whether flushing based local feed affect growth of Kejobong doe. 2. Study whether flushing based local feed affect the response of estrous, the initial of estrous, and the length of estrous. Twenty Kejobong does with average initial live weight $26.6 \pm 1.7 \mathrm{~kg}$ were used in this study. The animals were placed randomly into two feed treatments, namely: non-flushing ( $p 0)$ and flushing feed ( $p 1)$ with 10 replicates each. The observed variables were ADG, estrous response, the initial of estrous and the length of estrous. The difference value observed for the treatment of non-flushing and flushing analyzed by $t$ test. The results showed that the growth of Kejobong doe at flushing group was higher $(P \triangle 0.05)$ than non-flushing group. Response of estrous both in the group of nonflushing and flushing were 100\%. The initial of estrous of Kejobong doe from flushing group was more quickly than non-flushing $(P \unlhd 0.05)$. The length of estrous of flushing group was longer $(P \leq 0.05)$ than non-flushing group. It can br concluded that flushing on Kejobong doe can improve growth, accelerate the initial of estrous and prolong the length of estrous.
\end{abstract}

Key words: flushing, non-flushing, growth, estrous, Kejobong doe 


\section{PENDAHULUAN}

Kabupaten Purbalingga termasuk kedalam wilayah Eks Karesidenan Banyumas, dengan populasi kambing menempati urutan nomor dua setelah Kabupaten Banyumas, masing-masing sebanyak 165.089 ekor dan 284.347 ekor (Dinas Peternakan Propinsi Jawa Tengah, 2006). Pada umumnya, peternakan Kambing Kejobong di Kecamatan Kejobong Kabupaten Purbalingga adalah se-bagai usaha sampingan dan bertani tanaman singkong sebagai usaha pokok. Tujuan beternak kambing adalah untuk memperoleh penghasilan tambahan atau sebagai tabungan. Apabila peternak sedang butuh uang untuk keperluan keluarga, peternak tidak segan-segan menjual kambing betina di pasar lokal. Walaupun harga kambing betina pada saat itu sedang murah, misalnya pada saat men-jelang Hari Raya Idhul Adha, Konsumen utama dari kambing betina pada saat itu adalah penjual sate kambing, mengingat harga kambing jantan sangat mahal.

Menurut Ginting (2005), pakan lokal adalah setiap bahan baku yang merupakan sumberdaya lokal Indonesia yang dapat dimanfaatkan sebagai pakan berdaya guna bagi kambing, baik sebagai pakan tambahan, bagian dari pakan konsentrat, atau pakan dasar. Pakan lokal bagi kambing adalah bahan-bahan yang belum umum dimanfaatkan (inkonvesional), seperti (1) hasil sisa tanaman (crop residues), (2) hasil ikutan/samping/limbah tanaman (crop-by products), dan (3) hasil ikutan/ samping/limbah industri agro (agroindustry by products).

Kecamatan Kejobong sebagai salah satu wilayah kecamatan di Kabupaten Purbalingga merupakan penghasil singkong, di samping itu di daerah ini banyak dijumpai pabrik tepung tapioka yang banyak menghasilkan limbah industri berupa onggok. Walaupun produksi onggok berlimpah namun demikian, tidak pernah dimanfaatkan oleh peternak kambing sebagai bahan pakan lokal penyusun konsentrat. Di daerah ini, kambing diberi pakan yang utama adalah hijauan hasil menyabit di lahan bukan pertanian, seperti rumput lapangan, daun gliriside, dan daun singkong yang pada musim kemarau ketersediaannya terbatas. Kambing tidak pernah diberi pakan konsentrat baik sebelum maupun sesudah dikawinkan (flushing) dan atau sebagai pakan tambahan.

Muzani et al., (2000) menyatakan, flushing adalah upaya perbaikan kondisi tubuh ternak melalui pemberian pakan berkualitas tinggi pada waktu tertentu. Manfaat dari flushing ialah dapat meningkatkan hormon reproduksi, melancarkan birahi, dan meningkatkan jumlah ovum yang dilepaskan dari ovarium. Karikari dan Blasu (2009) mengemukakan bahwa, zat gizi pakan mempunyai peranan yang sangat penting bagi pengaturan reproduksi ternak. Menurut Johnson et al., (1990); Molle et al., (1995); Christian dan Jauhianen (2002), pada peternakan domba sudah biasa memberikan energi yang berlebihan (flushing) pada 2-3 minggu sebelum dan selama perkawinan.

Menurut Sabra dan Hassan (2008), flushing pada domba Barki betina selama satu bulan sebelum dikawinkan secara nyata dapat meningkatkan timbul-nya birahi dan memperpendek siklus birahi. Wildeus et al., (1989) melaporkan bahwa flushing pada domba bulu betina empat minggu sebelum kawin dapat memperlihatkan gejala birahi lebih awal pada musim kawin daripada domba betina non-flushing. Pemberian flushing + injeksi PG-600 pada Domba Barki betina, meningkatkan persentase birahi pada domba betina (Abu El-Ella, 2006). Smith (1962) menunjukkan bahwa, domba yang diberi pakan dengan konsentrasi energi yang lebih tinggi menunjukkan gejala berahi yang lebih tinggi. Younis et al., (1978) menemukan bahwa, domba Awassi yang diberi perlakuan zat gizi tinggi siklus birahinya lebih cepat daripada domba dengan zat gizi sedang. Ibrahim (1993), Muna et al., (1998) dan ElShamaa et al., (2003) melaporkan bahwa, perbedaan lama birahi pada antar perlakuan 
mungkin disebabkan karena banyaknya estrogen dalam darah yang diproduksi oleh penginduksian luteolisis; peningkatan konsentrasi estrogen dalam darah menyebabkan ternak menjadi birahi dan memiliki pengaruh yang menekan pada progesteron.

Menurut Robinson (1996); Bossis et al., (1999); dan Butler (2000), konsumsi energi me-ningkatkan glukose darah dan insulin yang dapat meningkatkan getaran sekresi LH dan memper-baiki tanggap ovarium terhadap stimulasi LH.

Menurut Owen dan Goetsch (1988) serta Aritonang (2009), pakan dengan konsentrasi energi tinggi akan menaikkan rasa enak, sehingga akan mendorong ternak untuk mengkonsumsi pakan. Salim et al., (2002) dan Marsetyo (2006) menyatakan, penambahan konsentrat meningkatkan bahan kering yang dimakan dan pemakaian bahan kering yang tinggi dapat meningkatkan pertambahan bobot badan harian atau PBBH. Menurut Crouse et al., (1978); Owen dan Goetsch, (1988); dan Belanger, (2001), energi yang cukup dalam pakan akan menaikkan penggunaan nitrogen makanan untuk sintesis dan penempatan protein tubuh. Sintesis protein dalam tubuh akan mendorong pertumbuhan pada tubuh ternak, yang ditunjukkan oleh pertambahan bobot badan. Menurut Aritonang (2009), sintesis protein dalam tubuh akan menciptakan pertumbuhan pada tubuh ternak, yang diujudkan dalam bentuk peningkatan bobot tubuh.

Menurut Patterson dan Corah (1993); Whittier et al., (1986); Suharyati, (1999); Adiati et al., (2006); Yudhie (2009), penyerentakan birahi merupakan suatu usaha untuk mengendalikan siklus birahi pada sekelompok ternak atau hewan betina dengan tujuan agar birahi terjadi dalam waktu yang hampir bersamaan.

Juma et al., (2009) melaporkan penyerentakan birahi pada kambing hitam dengan prosta-glandin (5 $\mathrm{mg} /$ dosis Dinoprost thromethamine, Lutalyse) yang disuntikkan secara intramuskular se-banyak dua kali dengan jarak waktu 11 hari atau 11-
12 hari (Herdis et al., 2007). Hasil penelitian menunjukkan bahwa tanggap birahi kambing betina masing-masing sebesar $100 \%$ dan $67 \%$. Bret-zlaff et al., (1981), menyuntikan dosis ganda terhadap kambing betina dengan prostaglandin $F_{2} \alpha$ $\left(\mathrm{PGF}_{2} \alpha\right)$ masing-masing sebanyak 1,$25 ; 2,5$; 5,0 dan 7,5 mg, $\mathrm{PGF}_{2} \alpha$ memberikan awal birahi tim-bul dari saat ternak disuntik adalah $(47 \pm 3,3)$ jam; $(42 \pm 4,3) ;(44 \pm 8,5)$ dan $(43 \pm 5,5)$ jam.

Menurut Maryono (2007), kambing di Kecamatan Kejobong mudah berkembang biak dan memiliki daging yang lebih empuk daripada Kambing Kacang dan Kambing Peranakan Etawa (PE). Berdasarkan hal tersebut, Pemerintah Daerah Kabupaten Purbalingga menyebut kambing yang berasal dari Kecamatan Kejobong adalah Kambing Kejobong. Listyarini et al., (1995); Murdianto et al., (2007); Nugroho et al., (2007); dan Yanto et al., (2007) mengamati Kambing Kejobong tentang sistim pemeliharaan, jumlah kepemilikan ternak, jenis pakan yang dimakan, warna bulu, raut muka, ukuran tubuh, bobot tubuh kambing dewasa berdasarkan jenis kelamin dan umur. Belum ada keterangan yang diperoleh tentang pemanfaatan pakan lokal yang diberikan secara flushing serta pengaruhnya terhadap tanggap birahi, awal birahi, dan lama birahi kambing Kejobong betina dewasa.

Penelitian ini bertujuan penelitian ini adalah untuk: 1. Mempelajari apakah flushing berbasis pakan lokal berpengaruh terhadap pertumbuhan (PBBH) kambing Kejobong betina dewasa. 2. Mempelajari apakah flushing berbasis pakan lokal berpengaruh terhadap tanggap birahi, awal birahi, dan lama birahi kambing Kejobong betina dewasa.

\section{MATERI DAN METODE}

\section{Ternak kambing}

Ternak kambing yang diteliti ini sebanyak 20 ekor kambing betina dewasa (2,5-3 tahun) dengan rataan bobot hidup 
Tabel 1. Komposisi dan kandungan nutrien pakan komplit

\begin{tabular}{|c|c|c|}
\hline \multirow[t]{2}{*}{ Bahan pakan } & $p_{0}$ & $p_{1}$ \\
\hline & \multicolumn{2}{|c|}{ |----------------------------------(\%)------------------------------- } \\
\hline \multicolumn{3}{|l|}{ Komposisi nutrien } \\
\hline Rumput lapangan & 50 & 50 \\
\hline Daun singkong & 30 & 30 \\
\hline Gliriside & 20 & 20 \\
\hline Onggok & - & 65 \\
\hline Dedak padi & - & 35 \\
\hline Ultra Mineral $^{1}(\mathrm{~kg})$ & - & 2 \\
\hline \multicolumn{3}{|l|}{ Kandungan nutrien } \\
\hline $\mathrm{BK}$ & 87,79 & 89,60 \\
\hline PK & 13,12 & 9,88 \\
\hline $\mathrm{TDN}^{3}$ & 45,17 & 49,27 \\
\hline \multicolumn{3}{|c|}{$\begin{array}{l}{ }^{1} \text { Setiap satu bungkus ( } 1 \mathrm{~kg} \text { ) Ultra mineral produksi Eka Farma Semarang, Jawa Tengah } \\
\text { Indonesia, mengandung Calcium Carbonat 50,00\%; Phosphor 25,00\%; Mangganese 0,35\%; } \\
\text { Jodium 0,20\%; Kalium 0,10\%; Cupprum 0,15\%; Sodium Chlorine 23,05\%; I r o n } 0,80 \% \text {; } \\
\text { Zincum 0,20\%; Magnesium 0,15\% } \\
{ }^{2} \text { Kelompok pakan III (Hartadi et al., 1980) }\end{array}$} \\
\hline
\end{tabular}

awal $26,6 \pm 1,7 \mathrm{~kg}$ dengan siklus birahi yang normal. Di samping itu, digunakan pula dua ekor kambing pejantan yang bertindak sebagai pengusik dan pemacek. Kambing tersebut ditempatkan pada kandang panggung dengan ukuran $75 \times 75 \times 75 \mathrm{~cm}$.

\section{Pakan}

Pakan yang diberikan kepada ternak terdiri dari hijauan dan konsentrat. Hijauan bertindak sebagai pakan basal dan diberikan kepada seluruh kambing betina dewasa dalam bentuk campuran yang meliputi rumput lapangan, daun singkong, serta daun gliriside. Hijauan tersebut diperoleh dari ladang yang terletak di sekitar rumah tempat tinggal petani.

Hijauan dipanen pukul 07.00 sampai dengan pukul 11.00, selanjutnya disimpan di dalam karung dan diberikan kepada ternak keesokan harinya pada pukul 15.00. Konsentrat yang diberikan kepada ternak merupakan campuran dari onggok dan dedak padi. Dedak padi dan onggok mudah diperoleh petani dalam jumlah yang cukup dan dengan harga yang terjangkau.

\section{Prosedur Penelitian}

\section{Pengelompokan ternak}

Dua puluh ekor kambing betina dewasa ditempatkan secara acak keda-lam dua macam perlakuan pakan, yaitu: perlakuan pakan non-flushing $\left(p_{0}\right)$ dan flushing $\left(p_{1}\right)$. Kedua perlakuan pakan tersebut masing-masing diulang sebanyak 10 kali. Komposisi dan kandungan nutrien dari kedua perlakuan pakan tersaji pada Tabel 1.

\section{Tatalaksana pemberian pakan}

Pakan basal masing-masing diberikan baik kepada ternak kelompok $p_{0}$ maupun kelompok $p_{1}$. Pakan basal yang diberikan kepada ternak kelompok $p_{0}$ dan kelompok $p_{1}$ dalam bentuk segar masingmasing sebanyak $2,5 \mathrm{~kg}$. 
Konsentrat dalam bentuk pelet hanya disajikan kepada ternak kelompok $p_{1}$. Jumlah konsentrat yang diberikan kepada ternak kelompok $p_{1}$ adalah 2,5 persen dari bobot badan ternak per ekor per hari. Perbandingan pakan basal dan konsentrat yang disajikan kepada ternak kelompok $p_{1}$ masing-masing sebesar 60\%:40\%.

Konsentrat yang ditambahkan kedalam pakan basal bertindak sebagai flushing, dan diberikan kepada ternak selama 34 hari berturut-turut 17 hari sebelum dan 17 hari sesudah ternak dikawinkan, selanjutnya disebut dengan perlakuan flushing atau $p_{1}$. Perlakuan non-flushing atau $p_{0}$ yang diberikan kepada kambing betina dewasa berupa pakan hijauan atau pakan basal. Pada hari yang ke-34 dan seterusnya, kambing betina dewasa pada kelompok $p_{0}$ dan kelompok $p_{1}$ masing-masing hanya diberi pakan basal secara ad libitum.

Konsentrat dan pakan basal disajikan kepada ternak sebanyak satu kali per ekor per hari masing-masing pada pukul 07.00 dan pukul 15.00. Air minum diberikan kepada ternak secara ad libitum.

\section{Penyerentakan birahi}

Penyerentakan birahi dilakukan dengan menyuntikkan larutan steril Lutalyse (B) (Dinoprost tromethamine) $100 \mathrm{ml}$ (C) Pharmacia \& Upjohn Company Kalamazoo, MI 49001, USA secara intramuscular melalui vena jugularis terha-dap semua kambing betina dewasa dengan dosis $1 \mathrm{ml}$ atau $5 \mathrm{mg}$ per ekor. Penyuntikan dua kali dengan selang waktu 11 hari dan dilakukan sebelum kambing diberi pakan pagi.

\section{Pengamatan birahi}

Pengamatan tingkah laku birahi $\left(\mathrm{D}_{0}\right)$ yang terdiri dari tanggap birahi (\%), awal birahi (jam), dan lama birahi (jam) terhadap semua ternak dilakukan selama dua hari setelah suntikan secara intramuskular dengan lutalyse yang kedua masing-masing pada jam ke-0, 24, 36 dan jam ke-48. Lama waktu pengamatan dari masing-masing jam pengamatan birahi adalah dua jam. Pejantan pengusik digunakan untuk membantu pengamatan birahi ternak betina.

\section{Tatalaksana perkawinan}

Kambing betina yang birahi dikawinkan dengan kambing pejantan (naturally mating systems) pada jam ke-36 selama $\mathrm{D}_{0}$ (hari ke-18 atau $\mathrm{D}_{1}$ ). Perka-winan antara pejantan dengan betina dilaksanakan di luar kandang pada waktu pagi hari, yakni antara pukul 07.00 - 09.00. Pejantan dibiarkan memilih betina yang birahi sampai terjadi perkawinan. Kambing betina yang tidak birahi lagi (kemungkinan bunting) kemudian dimasukkan kembali kedalam kandang indivi-du.

\section{Pengukuran PBBH}

Bobot badan kambing betina dewasa ditimbang setiap minggu dalam kurun waktu 34 hari. Sebelum ternak ditimbang bobot badannya, terlebih dahulu semua ternak dipuasakan selama kurang lebih 13 jam. Penimbangan ternak dilakukan sebelum ternak diberi pakan.

\section{Peubah yang diukur}

Peubah yang diamati adalah (1) konsumsi bahan kering, (2) konversi pakan (FCR), (3) PBBH, (4) tanggap birahi, lama birahi, dan awal birahi.

\section{Analisis Data}

Peubah PBBH dan birahi diekspresikan secara deskriptif dalam bentuk nilai rataan \pm simpang baku. Perbedaan nilai yang diamati karena perlakuan non-flushing dan flushing dianalisis dengan Uji t.

\section{HASIL DAN PEMBAHASAN}

\section{Flushing, PBBH, dan FCR}

Berdasarkan pada Tabel 2 bahwa, banyaknya energi TDN yang dimakan oleh kambing betina dewasa pada kelompok nonflushing dan kelompok flushing masing- 
Tabel 2. Perbandingan antara konsumsi dengan kebutuhan nutrisi bagi kambing betina dewasa (bahan kering basis)

\begin{tabular}{lccc}
\hline \hline Uraian & Kebutuhan $^{1}$ & \multicolumn{2}{c}{ Konsumsi } \\
\cline { 3 - 4 } & & $p_{0}$ & $p_{1}$ \\
\hline $\mathrm{BHA}^{2}, \mathrm{~kg}$ & 25 & 26,20 & 27,00 \\
$\mathrm{DMI}^{3}, \mathrm{~kg}$ & 0,71 & 0,43 & 0,71 \\
$\mathrm{E}^{-T D N}$ & \\
Total Protein, & 0,41 & 0,23 & 0,67 \\
PBBH, & 63 & 47 & 82,80 \\
$\mathrm{FCR}^{5}$ & 50 & $16^{\mathrm{a}}$ & $66^{\mathrm{b}}$ \\
\hline
\end{tabular}

$p_{0}=$ non-flushing

$p_{1}=$ flushing

${ }^{1}$ Philsan (1996)

${ }^{2}$ Bobot hidup awal

${ }^{3}$ Dry matter intake

${ }^{4} 1 \mathrm{~kg}$ TDN=3,62MkalME;0,23kgTDN =0,83MkalME;0,67kgTDN=2,43Mkal ME

${ }^{5}$ Feed conversion ratio $=\mathrm{DMI} / \mathrm{PBBH}$

${ }^{\mathrm{a}, \mathrm{b}}$ Superskrip yang berbeda pada baris yang sama adalah berbeda $(\mathrm{P} \leq 0,05)$

masing sebesar $0,23 \mathrm{~kg}$ dan $0,67 \mathrm{~kg}$ TDN. Hal ini berarti kambing pada kelompok nonflushing mengkonsumsi energi TDN lebih rendah daripada kebutuhan, sedangkan ternak pada kelompok flushing mengkonsumsi energi TDN lebih tinggi baik terhadap ternak pada kelompok non-flushing maupun dengan kebutuhan (Philsan, 1996). Diperoleh petunjuk bahwa, perlakuan $p_{1}$ atau flushing pada 17 hari sebelum dan 17 hari sesudah ternak dikawinkan, telah memenuhi kaidah flushing. Hal ini sesuai dengan pernyataan Johnson et al., (1990); Molle et al., (1995); Luginbuhl dan Poore (1998); Luginbuhl dan Kem (2000); Christian dan Jauhianen (2002), penyediaan energi tinggi kepada ternak sebelum dan sesudah perkawinan disebut flushing.

Berdasarkan pada Tabel 2 dapat diperhatikan bahwa, banyaknya bahan kering yang dimakan oleh ternak pada kelompok flushing lebih tinggi daripada kelompok non-flushing. Hal tersebut diikuti oleh meningkatnya pemakaian energi dan pemakaian protein pakan pada ternak kelompok flushing (Tabel 2). Hal ini sesuai dengan pernyataan Owen dan Goetsch (1988) serta Aritonang (2009), pakan dengan tingkatan energi tinggi menaikkan rasa enak, sehingga akan mendorong ternak untuk mengkonsumsi pakan. Lebih banyak pakan yang dikonsumsi maka lebih banyak pergerakkan pakan dalam saluran pencernaan, sehingga saluran pencernaan dengan cepat menjadi kosong. Oleh karena itu, ternak akan terus makan yang menyebabkan jumlah bahan kering serta gizi yang dimakan akan meningkat. Di samping itu, penambahan konsentrat yang disajikan secara flushing pada kambing betina dewasa dapat meningkatkan bahan kering yang dimakan. Hal ini sesuai dengan laporan Salim et al., (2002) bahwa, penambahan konsentrat meningkatkan bahan kering yang dimakan. Tingginya bahan kering dan protein yang dimakan pada pakan berenergi yang lebih tinggi (kelompok flushing) diikuti oleh $\mathrm{PBBH}$ yang lebih tinggi $(\mathrm{P} \leq 0,05)$ daripada ternak pada kelompok nonflushing. Diperoleh petunjuk bahwa, bahan kering yang dimakan oleh kambing betina dewasa pada kelompok flushing dapat meningkatkan PBBH yang lebih tinggi daripada ternak pada kelompok nonflushing. Keadaan ini sesuai dengan laporan Salim et al., (2002) dan Marsetyo (2006), pemakaian bahan kering yang tinggi dapat meningkatkan PBBH. Menurut Crouse et al. 


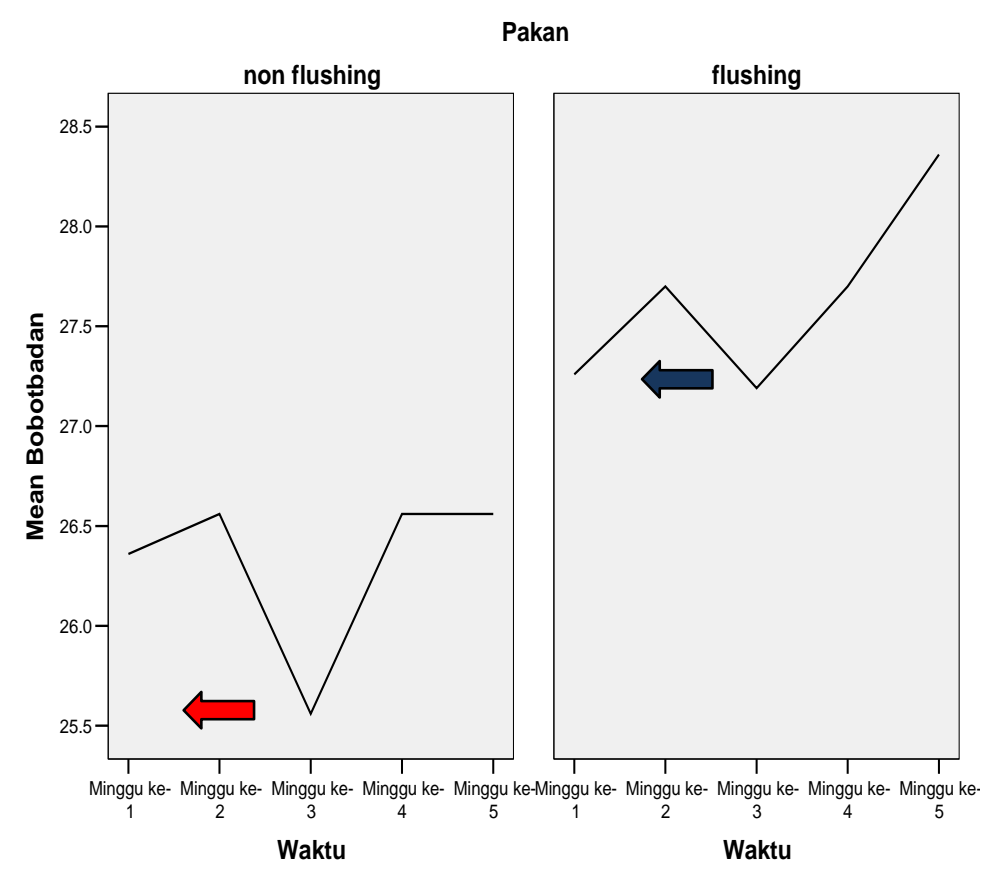

Gambar 1. PBBH kambing betina dewasa lokal Kejobong (non-flushing dan flushing)

(1978); Owen dan Goetsch, (1988); dan Belanger, (2001), energi yang cukup dalam pakan akan menaikkan penggunaan nitrogen makanan untuk sintesis dan penempatan protein tubuh. Sintesis protein dalam tubuh akan mendorong pertumbuhan pada tubuh ternak, yang ditunjukkan oleh pertambahan bobot badan.

Kambing Kejobong betina dewasa pada saat birahi $\left(\mathrm{D}_{0}\right)$ setelah dikawinkan dengan pejantan pada hari yang ke-18 menunjukkan penurunan bobot badan, untuk kelompok ternak yang hanya diberi pakan basal dan kelompok flushing masing-masing sebesar 25,56 kg dan 27,19 kg (Gambar 1). Hal tersebut disebabkan karena pada saat birahi, ternak menjadi kurang nafsu makan yang menyebabkan bobot badan turun. Ternak yang birahi menunjukkan perubahan perilaku di antaranya adalah nafsu makan menurun (Partodiharjo, 1987; Murtidjo, 1993; dan Priyono, 2009).

Berdasarkan Tabel 2 dapat diperhatikan bahwa, FCR kambing betina pada kelompok flushing dan yang hanya diberi pakan basal masing-masing adalah 10,8 dan 26,9. Diperoleh petunjuk bahwa kemampuan untuk mengubah satu satuan kilogram pakan bahan kering menjadi satu satuan kilogram PBBH kambing betina pada kelompok flushing memiliki FCR yang lebih baik daripada kelompok ternak yang hanya diberi pakan basal.

\section{Penyerentakan Birahi}

Penyerentakan birahi dilakukan terhadap kambing betina dewasa baik pada kelompok flushing maupun non-flushing. Penyerentakan birahi menggunakan preparat hormon prostaglandin yang disuntikan secara intramuskular $(5 \mathrm{mg} /$ dosis Dinoprost thromethamine, Lutalyse) sebanyak dua kali dengan selang waktu 11 hari. Tindakan tersebut sesuai dengan penda-pat Herdis et al., (2007) dan Juma et al., (2009) bahwa, jika penyerentakan birahi dilakukan dengan tanpa memperhatikan ada tidaknya corpus luteum, penyuntikan PGF2 $\alpha$ dilakukan dua kali dengan selang waktu 11-12 hari.

Hasil penelitian menunjukkan bahwa, penyerentakan birahi terhadap kambing betina dewasa pada kelompok flushing dan non-flushing menghasilkan 
Tabel 3. Tanggap birahi, awal birahi, dan lama birahi

\begin{tabular}{lcc}
\hline \hline Peubah & \multicolumn{2}{c}{ Perlakuan } \\
\cline { 2 - 3 } & $p_{0}$ & $p_{1}$ \\
\hline $\mathrm{n}$ & 10 & 10 \\
Tanggap birahi (\%) & 100 & 100 \\
Awal birahi (jam) & $37,40 \pm 0,45^{\mathrm{a}}$ & $36,30 \pm 0,31^{\mathrm{b}}$ \\
Lama birahi (jam) & $36,54 \pm 0,25^{\mathrm{a}}$ & $37,78 \pm 0,54^{\mathrm{b}}$ \\
\hline$p_{0}:$ non-flushing & & \\
$p_{1}$ : flushing & & \\
a, b Superskrip pada baris yang sama adalah berbeda $(\mathrm{P} \leq, 05)$
\end{tabular}

tanggap birahi masing-masing sebanyak $100 \%$ dan $100 \%$. (Tabel 3). Hal ini berarti penyerentakan birahi terhadap semua ternak baik yang ada pada kelompok flushing dan non-flushing memberikan tanggap birahi yang bersamaan. Penyerentakan birahi pada kambing betina dapat menimbulkan birahi yang hampir bersamaan (Patterson dan Corah 1993; Whittier et al., 1986; Suharyati, 1999; Adiati et al., 2006); dan Yudhie, 2009. Timbulnya birahi yang bersamaan pada ternak disebabkan karena kehadiran preparat prostaglandin $\quad\left(\mathrm{PGF}_{2} \alpha\right) \quad$ sehingga menyebabkan kemunduran fungsi corpus luteum yang disebabkan karena luteolitik. Secara alami $\mathrm{PGF}_{2} \alpha$ dilepaskan oleh uterus hewan yang tidak bunting dan berfungsi menghancurkan corpus luteum. Penyuntikan $\mathrm{PGF}_{2} \alpha$ kepada kambing betina menimbulkan birahi dikarenakan hancurnya corpus luteum sebagai akibat kerja vasokontriksi $\mathrm{PGF}_{2} \alpha$, sehingga aliran darah yang menuju corpus luteum sangat menurun. Hal ini menyebabkan tingkatan progesteron yang dihasilkan corpus luteum dalam darah menurun. Penurunan tingkatan progesteron merangsang hipofisa anterior untuk melepaskan FSH dan LH. Kedua hormon tersebut bertanggung jawab dalam proses folikulogenesis dan ovulasi yang menyebabkan folikel tumbuh dan matang. Pada akhirnya, folikel-folikel tersebut menghasilkan hormon estrogen yang merang-sang timbulnya gejala birahi. Menurut Partodihardjo (1987); Bauern-feind dan Holtz, (1991); Riesenberg et al., (2001); dan Husnarizal (2008), kerja hormon estrogen ialah untuk meningkatkan kepekaan alat kelamin betina, berperan penting pada fisiologi reproduksi seekor betina, dan merangsang timbulnya birahi. Diperoleh petunjuk bahwa suntikan secara intramuskular dengan prostaglandin (5 $\mathrm{mg} /$ dosis Dinoprost thromethamine, Lutalysae) sebanyak dua kali dengan selang waktu 11 hari dapat diterapkan untuk penyerentakanbirahi pada Kambing Kejobong betina dewasa.

\section{Awal birahi dan lama birahi}

Berdasarkan pada Tabel 3, penyerentakan birahi terhadap kambing betina dewasa pada kelompok flushing memperlihatkan awal birahi yang lebih cepat daripada ternak pada kelompok non-flushing $(\mathrm{P} \leq 0,05)$. Lama birahi kambing betina dewasa pada kelompok flushing $(\mathrm{P} \leq 0,05)$ lebih lama daripada kelompok non-flushing $(\mathrm{P} \leq 0,05)$. Diperoleh petunjuk bahwa, flushing pada kambing betina dewasa dapat mempercepat timbulnya awal birahi dan memperpanjang lama birahi. Hal ini disebabkan karena kambing betina yang diberi pakan basal ditambah konsentrat yang diberikan secara flushing, dapat meningkatkan aktivitas hipotalamus dan sekresi GnRH. Akibatnya, terjadi perubahan-perubahan hormon ovarium dari alat reproduksi betina yang dapat merangsang timbulnya birahi. Gordon (1999) mengemukakan peningkatan pe- 
nampilan tingkah laku birahi disebabkan karena pengaruh flushing pada aktivitas hipotalamus (hypothalamic activity) dan sekresi GnRH. Pengaruh pada penampilan reproduksi dijembatani oleh perubahanperubahan pada hormon-hormon ovarium atau pada hypothalamic-pituitary sensitivity terhadap hormon-hormon ovarium. Hasil ini sesuai dengan pernyataan Smith (1962) bahwa domba yang diberi pakan dengan tingkatan energi yang lebih tinggi menunjukkan gejala birahi yang lebih tinggi. Younis et al., (1978) menemukan bahwa, domba Awassi yang diberi perlakuan nutrisi tinggi siklus birahinya lebih cepat daripada domba dengan zat gizi sedang. Wildeus et al., (1989) melaporkan bahwa, domba bulu betina yang diberi pakan secara flushing dalam jangka waktu empat minggu sebelum dikawinkan menunjukkan birahi lebih awal pada musim kawin daripada domba yang tidak diberi flushing. Abu El-Ella (2006) menyatakan bahwa, penggunaan flushing untuk jangka waktu yang lama telah dilaksanakan pada peternakan komersial domba guna mencapai kesuburan (fecundity) yang lebih tinggi. Infor-masi terakhir menunjukkan bahwa pengaruh peningkatan tingkatan zat gizi pada fungsi hypothalamus pituitary terlihat dalam beberapa hari. Diperoleh petunjuk bahwa, pengaruh flushing adalah lebih nyata ketika diberikan pada fase folikular dari siklus birahi. Informasi ini menyarankan bahwa kemungkinan penggunaan flushing dalam jangka pendek merupakan cara yang lebih murah dan praktis yang dapat diterapkan di bawah kondisi komersial. Hal ini adalah layak bila dilakukan bersama-sama dengan kegiatan penyerentakanbirahi.

Pada Tabel 3 dapat diperhatikan bahwa, alwal birahi kambing betina dewasa pada kelompok flushing dan non-flushing masing-masing sebesar $(36,300 \pm 0,3127)$ jam dan $(37,400 \pm 0,4473)$ jam. Hasil ini lebih baik daripada hasil yang dilaporkan Bretzlaff et al., (1981) yang menyuntikan dosis ganda terhadap kambing betina dengan prostaglandin $\mathrm{F}_{2} \alpha\left(\mathrm{PGF}_{2} \alpha\right)$ sebanyak 1,25 mg $\mathrm{PGF}_{2} \alpha$ diperoleh awal birahi sebanyak $(47 \pm 3,3)$ jam.

Berdasarkan Tebel 3 lama birahi kambing betina dewasa baik kelompok flushing maupun kelompok non-flushing masing-masing sebesar $(37,780 \pm 0,5432)$ jam dan $(36,540 \pm 0,2459)$ jam. Lama birahi tersebut berbeda dengan hasil temuan Devendra dan McLeroy (1982) dan Cupps (1991) yang melaporkan bahwa, lama birahi kambing adalah 24-36 jam. Perbedaan tersebut disebabkan karena pemberian flushing pada Kambing Kejobong betina dewasa yang berpe-ngaruh terhadap sintesis hormon reproduksi yang menyebabkan lama birahi menjadi lebih panjang. Ibrahim (1993), Muna Ahmad et al., (1998) dan ElShamaa et al., (2003) melaporkan bahwa, perbedaan lama birahi pada antar perlakuan mungkin disebabkan karena banyaknya estrogen dalam darah yang diproduksi oleh penginduksian luteolisis; peningkatan aras estrogen dalam darah menyebabkan ternak menjadi birahi dan memiliki pengaruh yang menekan pada progesteron.

\section{KESIMPULAN}

Berdasarkan hasil penelitian ini dapat disimpulkan bahwa flushing berbasis pakan lokal meningkatkan $\mathrm{PBBH}$ dan tanggap birahi, mempercepat awal birahi serta memperpanjang lama birahi kambing Kejobong betina dewasa.

\section{DAFTAR PUSTAKA}

Abu-El-Ella, A.A. 2006. Response of Barki Ewes to Treatment with Gonadotrophin Hormones and Energy Supplementation (Flushing). Egyptian Journal of Sheep, Goat and Desert Animal Science. 1 (1): 73-88.

Adiati, U., D.A. Kusumaningrum, B. Tiesnamurti, dan D. Priyanto. 2006. Penyerentakkan Birahi pada Ternak Domba dengan Berbagai Level Konsentrasi Fluorogestone Acetate. Seminar Nasional Teknologi Peternakan dan Veteriner 2006. http://peternakan.litbang.deptan.go.id/publi 
kasi/semnas/Pro06-56.pdf. Diakses 8 Januari 2010 06:12:40 GMT

Aritonang, S. N. 2009. The Effect of Forage Energy Level on Production and Reproduction Performances of Kosta Female Goat. Pakistan Journal of Nutrition 8 (3): 251-255. Asian Network for Scientific Information.

Bauernfeind, M. and W. Holtz, 1991. Progesteron and Estrogen Arass in Serum of Cycling Goats Measured by Enzyme Immunoassay. Small Rumin. Res., 6:95102.

Belanger, J., 2001. Storey Guide to Raising Dairy Goats. Storey Publishing.North Adam, p: 72-81.

Bossis, I., R.P. Wettemaann, S.D. Welty, J.A. Vezearra, L.J. Spicer and M.G. Diskin, 1999. Nutritionally Induced an Ovulation in Beef Heifer, Ovarium and Endocrine Functions Preceding Cessation of Ovulation. Journal of Animal Science, 77: 1536-1546.

Bretzlaff, K.N. , R.S. Ott, P.G. Weston and J.E. Hixon, 1981. Doses of Prostaglandin F2 $\alpha$ Effective for Induction of Estrus in Goats. Theriogenology. Vol. 16, Issue 5, Pages 587-591

Butler, W.R. 2000. Nutritional Interaction with Reproductive Performance in Dairy Cattle. Journal of Animal Reproduction Science, 60: 449-457.

Christian, R.S. and L. Jauhianinen. 2002. Effect of Nutritional Flushing on the Productivity of Finnish Landrace Ewes. Small Ruminant Research. Elsevier.

Crouse, J.D., R.A. Field. J.L. Chant Jr., C.L. Ferrel, G.M. Smith and V.L. Harrison, 1978. The Effect of Dietary Energy Intake on Carcass Composition and Palatability of Different Weight

Carcass from Ewe and Ram.J. Anim. Sci., 47: 1207-1218.

Cupps, P.T. 1991. Reproduction in Domestic Animals. 4th Edition. Academic Press. New York and London.

Devendra, C. and G.B. Mc. Leroy, 1982. Goat and Sheep Production in The Tropics. Longman Group. London, p; 61-67, 100.
Dinas Peternakan Provinsi Jawa Tengah. 2006. Data Base Peternakan Jawa Tengah. Tri Bulan I. Tarubudaya Ungaran. Dari: http://www.kadispernak@jawatengah.go.id Diakses 9 Januari 2007 06:12:40 GMT

El-Shamaa, I.S., A.A. Sallam, and I.M. Abd El Razek. 2003. Effect of Prostaglandin F-2 $\alpha$ Dosage and Route of Administration on Estrus Induction in Romanov Crossbred Ewes during the End of Breeding Season. J.Agric. Res. Tanta Univ., 29 (3): 387-398.

Ginting, S.P. 2005. Tantangan dan Peluang Pemanfaatan Pakan Lokal untuk Pengembangan

Peternakan Kambing di Indonesia. Makalah Lokakarya Nasional. Pusat Penelitian dan Pengembangan Peternakan, Bogor.

Gordon, I. 1999. Controlled Reproduction in Sheep and Goat. CAB International.

Hartadi, H., L.C. Kearl, S. Reksohadiprodjo, L.E. Harris, S. Lebdosukojo dan A.D. Fillman. 1980. Tabel-tabel dari Komposisi Bahan Makanan. Data lmu Makanan Ternak untuk Indonesia. (Logan, Utah: The International

Feedstuff Institute Utah Agricultural Experiment Station, Utah State University.

Herdis, I., Kusuma, M. Surachman,dan E.R. Suhana. 2007. Peningkatan Populasi dan Mutu Genetik Sapi. http://kenshuseidesu.tripod.com/id46.html. direkam pada 15 Agustus 2010 06:42:40 GMT.

Husnarizal. 2008. Sinkronisasi Birahi dengan Preparat Hormon Prostaglandin (PGF2 $\alpha$ ). Fakultas Kedokteran Hewan Universitas Syiah Kuala.

Ibrahim, A.M.A. 1993. Controlling some Reproductive Characteristics of Sheep. M. Sc. Thesis, Faculty of Agriculture, AlAzhar Univ, Egypt.

Johnson, W.L., Barros, N.N. and E.R. Oliveira. 2001. Supplemental Feed Resources and Their Utlization by Hair Sheep. In: M. Shelton and E.A.P. Figueiredo (Eds), Hair Sheep Production in Tropical and SubTropical Regions with Reference to Northeast Brazil and the Countries of the Caribean,Central America, and South America, Small Ruminant Collaborative 
Research Support Program, Davis, CA,pp: 79-95.

Juma, F.T., N. N. Maroff and K. T. Mahmood. 2009. Effect of Some Hormones on Reproductive Performance and Some Serum Biochemical Changes in Synchronized Black Goats. Iraqi Journal of Veterinary Sciences, Vol. 23, No. 2, (5761).

Karikari, P.K., and E.Y. Blasu. 2009. Influence of Nutritional Flushing Prior to Mating on the Performance of West African Dwarft Goats Mated in the Rainy Season. Livestock Research for Rural Development 21 (7).

Listyarini, I.T., M. Socheh, dan B. Haryanto. 1995. Ukuran Linier Tubuh dan Pola Warna Kambing Lokal Kejobong di Kabupaten Dati II Purbalingga (Studi Kasus). Skripsi S1. Fakultas Peternakan, Universitas Jenderal Soedirman. Purwokerto.

Luginbuhl J.M., and M.H. Poore. 1998 Nutrition of Meat Goats. From http://www.cals.ncsu.edu/ansci/extension/a nimal/meatgoat/MGNutr.htm. Direkam pada 15 Maret 2010 14:44:30 GMT.

Luginbuhl, M.J., and L.E. Kem. 2000. How to Prepare Goats for the Breeding Season. http://www.cals.ncsu.edu/ansci/extension/a nimal/meat-goat $/ \mathrm{mg}$ Breeding.htm. direkam pada 2 Mei 2008 22:49:45 GMT.

Marsetyo, 2006. Pengaruh Penambahan Daun Lamtoro atau Bungkil Kelapa Terhadap Konsumsi, Kecernaan Pakan dan Pertambahan Bobot Kambing Betina Lokal yang Mendapatkan Pakan Dasar Jerami Jagung. Jurnal Protein. Vol. 13. No. 1. Tahun 2006

Maryono, 2007. Produktivitas Kambing Kejobong. Hasil Wawancara dengan Ketua Kelompok Peternak Kambing Ngudidadi Kecamatan Kejobong. Kabupaten Purbalingga.

Molle, G., A. Branca, S. Ligios, M. Sitzia, S. Casu, S. Landau, and Z. Zoref. 1995. Effect of Grazing Background and Flushing Supplementation on Reproductive Performance in Sarda Ewes. Small Rum. Res. 17:245-254.
Muna A.M.M., S.E. Makaw, and Jubara. A.S. 1998. Synchronization of Oestrus in Nubian Goats. Small Rumin.Res.30:113-120.

Murdianto, D., A. Sodiq, dan I. Haryoko. 2007. Karakteristik Bobot Tubuh Kambing Dewasa Berdasarkan Jenis Kelamin dan Umur di Kecamatan Kejobong, Kabupaten Purbalingga. Skripsi S1. Fakultas Peternakan, Unsoed.

Murtidjo, B.A. 1993. Memelihara Kambing Sebagai Ternak Potong dan Perah. Kanisius. Yogyakarta. Hal 31-35, 76-91.

Muzani, A., A. Wildan, A. Sauki, W.R. Sasongko, dan S. Farida. 2000. Teknologi Fushing pada Kambing Peranakan Etawah. Rekomendasi Teknologi Pertanian. IPPTP. Mataram.

Nugroho, A., A. Sodiq, dan P. Yuwono. 2007. Profil Kepemilikan Ternak Kambing Berdasarkan Umur Fisiologis, Tinggi Pundak dan Warna Tubuh Dominan di Kecamatan Kejobong, Kabupaten Purbalingga. Skripsi S1. Fak. Peternakan, Unsoed.

Owen, F.N., and A.L. Goetsch, 1988. Ruminal Fermentation. In: Church (Ed)-The Ruminant Animal. Digestive Physiology and Nutrition. Prentice Hall. New Jersey, p: 145-147.

Partodihardjo, S. 1987. Ilmu Reproduksi Hewan. Cetakan ke 2. Mutiara Sumber Widya. Pulogadung, Jakarta. 599 hal.

Patterson, D.J., and L.R. Corah. 1993. Evaluation of a MGA and PGF2 $\alpha$ System for The Synchronization of Estrus in Beef Hifers. Anim. Breeds. Abstract. 6 (13):154.

Philsan, 1996. Feed Reference Standards. Second Edition. Philippine Copyright.

Poney J.N., A.N. Ishar, dan R.A. Singh. 1985. Oestrus Synchronized in Goat Using Prostaglandin (Lutalyse). J. Anim Sci. 55; 551-552.

Priyono. 2009. Mengenali Gejala Birahi Untuk Inseminasi Ternak Kambing. Dari http://www.priyonoscience.blogspot.com/ 2009/10/mengenali-gejala-birahiuntuk.html\# direkam pada 23 Desember 2009 15:18:45 GMT.

Riesenberg, S., S. Meinecke-Tillmann, and B. Meinecke, 2001. Estradiol 17- $\beta$ and 
Progesterone in The Peripheral Blood Plasma of Goats Following SuperOvulation With a Single Dose of pFSH, hMG or eCG. Small Rum. Res., 40:73-82.

Robinson, J.J. 1996. Nutrition and Reproduction. J. Anim. Reprod. Sci. 65: 157-170

Sabra, H.A. and S.G. Hassan. 2008. Effect of New Rezime of Nutritional Flushing on Reproductive Performances of Egyptian Barki Ewes. Global Veterinaria 2(1): 28-31.

Salim, H.M., M. Shahjalal, A.M.M. Tareque, and F. Kabir. 2002. Effects of Concentrate Supplementation on Gand Reproductive Performance of Female Sheep and Goats under Grazing Condition. Pakistan

Smith, J. D. 1962. The Effect of Plan of Nutrition Upon the Incidence of Oestrous in The MerinoEewe in Queenland. Aust. Vet. J., 38: 338.

Suharyati, S. 1999. Pengaruh Pemberian Pregnant Mare Serum Gonadotrophi dan Human Chorionic Gonadotrophin Terhadap Kinerja Reproduksi Kambing Peranakan Etawah yang Disinkronisasi Estrus dengan Progesteron. Tesis. Fakultas Pascasarjana, UGM. Yogyakarta.
Whittier, J.C., G.H Deutcher, and D.C. Clanton. 1986. Progesterone and Prostaglandin for Etrus Synchronization in Beef Heifer. J. Anim. Sci. 63: 700-704.

Wildeus, S., K.T. Traugott, and J.R. Fugle. 1989. Effects of Pre-bBreeding Supplementation on Body Weight and Reproductive Characteristics in Multiparous and Nulliparous St Croix sheep. J. Anim. Sci. 64, 67.

Younis, A.A., El-Gaboory, I.A.; El-Tawil, E.A. and El-Shobokshy, A.S. 1989. Age at Puberty and Possibility of Early Breeding in Awassi Ewes. J. Agric. Sci. Comb., 90: 255.

Yudhie. 2009. Teknik Sinkronisasi Estrus pada Sapi.

http://yudhieestar.blogspot.com/2009/12/ teknik-sinkronisasi-estrus-pada-Sapi.html.

Direkam pada 8 Januari 2010 06:45:40 GMT.

Yanto, A.B., A. Sodiq, dan B. Haryanto. 2007. Karakteristik Sifat Kualitatif (pola warna, roman nose, garis punggung) dan Ukuran Telinga Kambing Kejobong di Kecamatan Kejobong, Kabupaten Purbalingga. Skripsi S1. Fakultas Peternakan, Unsoed. 